\title{
Fé que salva, segundo Gálatas e Tiago
}

\section{Faith that Saves, according to Galatians and James}

Johan Konings

\section{Resumo}

$\mathrm{O}$ artigo que aqui apresentamos tem por objetivo contribuir para a compreensão de fé e obras na Carta de Tiago e na Carta de Paulo aos Gálatas. É preciso estudar os textos bíblicos antes de tudo na comunidade de comunicação que se constitui entre o autor e destinatário, e não a partir de questões teológicas ulteriores, que podem ser consideradas depois, ao avaliar o processo hermenêutico histórico. Aplicamos esse princípio a dois textos que geralmente são vistos como estando em diálogo ou em polêmica, a Carta aos Gálatas e a Carta de Tiago, estudando-os como textos autônomos, que utilizam de modo autônomo o paradigma sapiencial tradicional da fé de Abraão, sem excluir que, factualmente, Tiago pode conter uma resposta a uma interpretação errônea da salvação pela fé em Gálatas. Fé que salva é a adesão fiel a Jesus Cristo verificada na práxis cristã que Paulo chama o fruto do Espírito.

Palavras-chaves: Fé. Salvação. Justificação. Sabedoria. Práxis cristã.

\section{Abstract}

The present article aims to contribute to the understanding of faith and works in the Letter of James and in Paul's Letter to the Galatians. It is necessary to study the biblical texts first of all in the communication community constituted between the author and the recipient, and not in dependence of ulterior theological questions, which can then be considered when evaluating the historical hermeneutic process. We apply this principle to two texts that are generally seen as being in dialogue or in controversy, the Letter to the Galatians and the Letter of James, studying them as autonomous texts, that use 
autonomously the traditional wisdom paradigm of Abraham's faith, without excluding that, in fact, James may contain a response to a misinterpretation of salvation by faith in Galatians. Faith that saves is the faithful adhesion to Jesus Christ verified in the Christian praxis that Paul calls the fruit of the Spirit.

Keywords: Faith. Salvation. Justification. Wisdom. Christian praxis.

\section{Introdução}

O objetivo deste artigo é comparar dois textos que falam sobre a salvação pela fé, a saber, a Carta aos Gálatas e a Carta de Tiago. Contudo, a terminologia da "salvação" não ocorre em Gálatas, que prefere "justificação", utilizada em uma única passagem em Tiago (2,21-26). Instalou-se a opinião de que Tiago contradiz ou corrige Gálatas nesse quesito, mas uma leitura independente de ambos os textos mostra que não é necessariamente assim. A leitura de superfície dos dois textos não revela polêmica ou oposição, muito menos contradição, mas dois discursos autônomos e, quanto ao proveito do leitor, complementares. Procuramos, portanto, não opor os dois textos como "adversários", mas perceber a mensagem comum e as nuances próprias de cada um.

Ao abordar este assunto cabem algumas observações prévias.

1) Quando se fala em confrontar Tiago e Gálatas, logo se pensa no tema da justificação. Porém, a justificação é, mesmo nos escritos paulinos, apenas uma das metáforas para expressar a salvação segundo a fé cristã. Fora das Cartas aos Romanos e aos Gálatas, a justificação não aparece como tema maior nem mesmo nos escritos paulinos. Por isso usamos a terminologia mais comum, igualmente metafórica: "salvação", apesar da dificuldade de circunscrever seu referente. ${ }^{1}$

\footnotetext{
${ }^{1}$ A terminologia da salvação pertence ao domínio semântico da ajuda na necessidade, guerra, opressão, enfermidade etc. Na Bíblia e na Teologia (soteriologia), muitas vezes, significa a preservação total e definitiva do mais radical perigo ou ameaça, referindo-se à ordem da ação divina e da escatologia (PENNA, R., Salvação, p. 1591-1596). É importante lembrar que a salvação e as metáforas equivalentes não se referem apenas ao resultado final ("os Últimos"), mas ao processo que, da parte do ser humano, se inicia desde a fé inicial (At 2,47, sōzomenoi, "os sendo salvos"), através da fidelidade de toda uma vida, com eventuais quedas e reerguimentos. - A terminologia "salvar/salvação" não aparece em Gálatas, mas é frequente nas cartas aos Romanos e aos Coríntios, bem como em Atos, e inclui o aspecto da justificação, menos
} 
2) É importante ler os textos de Tiago e de Paulo em seu próprio quadro e intenção, não um em dependência do outro, pois, apesar do que geralmente se pensa, não há evidência externa de que um esteja reagindo ao outro. A análise exegético-bíblica deve tentar compreender a comunicação originária acontecida na comunidade de compreensão constituída pelo autor e seu leitorado; não pode ser refém de desenvolvimentos dogmáticos ou polêmicos ulteriores, por mais legítimos que sejam para a teologia sistemática. A hermenêutica estabelece um diálogo entre nossa compreensão hoje e a compreensão originária da "coisa" que o texto evoca. Convém ter consciência (ou desconfiança) de que compreensões menos originárias podem ter moldado nossa compreensão. O papel da exegese histórico-literária é, precisamente, recuar por trás dessas camadas interpretativas ulteriores, que condicionam a nossa leitura, e estabelecer o diálogo com a compreensão originária: "compreender a compreensão primeira" (sem negar que as compreensões ulteriores podem revelar um potencial de sentido latente na comunicação originária).

3) Além disso, tenha-se consciente que o conceito intelectual não é a única maneira de trazer à nossa presença a "coisa" do texto. A compreensão não se refere necessariamente a conceitos teológicos, mas talvez à percepção de uma práxis.

\section{Gálatas}

\subsection{Contexto situacional}

A Carta aos Gálatas é geralmente situada, pelos estudiosos, entre 55 e 60 d.C., pouco antes da Carta aos Romanos. ${ }^{2}$ Seria portanto anterior à Carta de Tiago, geralmente datada por volta de $80-90 .^{3}$ Ambas tratam da justificação pela fé, Gálatas de modo extenso, Tiago tangencialmente.

abrangente (PENNA, Salvação, p. 1594-1595). Ver também WILLIANS, R., Justificação, p. 974 980. Quanto à compreensão teológica atual é imperativo conhecer a Declaração Conjunta sobre a Doutrina da Justificação, da Igreja Católica e da Federação Luterana mundial (DH 5073-5074). ${ }^{2}$ BROWN, R. E., Introdução ao Novo Testamento, p. 738, situa Gálatas em 54/55 d.C. (p. 622), Romanos em 57/58 (ou 55/56).

${ }^{3}$ Esta é a opinião crítica corrente. BROWN, R. E., Introdução ao Novo Testamento, p. 947. Se a carta tiver sido enviada na vida ou logo depois da morte de Tiago, em 62 d.C., deve-se pensar no período entre 60 e 70 d.C. 
O contexto situacional de Gálatas parece ter sido que missionários cristãos "judaizantes", como Paulo os chama (G1 2,14), incentivaram os gentios na Galácia ${ }^{4}$ a se tornarem judeus, adotando a circuncisão e a Lei de Moisés, coisa inaceitável para Paulo, que rompera com o regime mosaico para assumir a "Lei de Cristo" (Gl 6,2). Essa situação deve ter-se produzido algum tempo depois do assim chamado "Concílio de Jerusalém", por volta de 49 d.C., que tratou da acusação apresentada por alguns missionários da Antioquia contra Paulo e Barnabé, por admitirem os gentios sem a circuncisão (At 15,1-5). Situação análoga pode ter-se repetido algum tempo depois (apesar de a reunião já ter resolvido a questão), no episódio envolvendo Pedro e Barnabé em Antioquia (Gl 2,11-14) e no conflito de Paulo com os judaizantes na Galácia (G1 1,6-10; 3,1-5). ${ }^{5}$

Embora nem Lucas, nem a Carta aos Gálatas proporcionem uma sequência cronológica stricto sensu, pode-se esboçar um quadro temporal aproximativo. $^{6}$

- Cerca de 35 d.C.: conversão de "Saulo" e temporada de alguns anos na Arábia e Damasco (Gl 1,15-17).

- Pouco depois: encontro de Saulo com “as colunas” em Jerusalém (G1 1,18-24; At 9,25-30).

- Saulo em Cilícia (Tarso), até o chamado de Barnabé (At 11,25 em diante), quando adota o nome de "Paulo" (At 13,9) e acompanha Barnabé na evangelização em Chipre, na Panfília e em Antioquia da Síria ( $1^{a}$ viagem de missão, At 13-14).

- Cerca de 49 d.C.: Paulo na reunião dos apóstolos em Jerusalém (Gl 2,110; At 15,4-35).

- Depois disso, Paulo volta à Cilícia e à Ásia Menor, com Silas (Silvano), mas sem Barnabé e Marcos (que ficam em contato com Pedro) $\left(2^{a}\right.$ viagem de missão, At 15,16-18,22).

\footnotetext{
${ }^{4} \mathrm{O}$ termo "Gálacia”, usado somente em 1,2, indica provavelmente a região específica dos gálatas no interior da Turquia (sentido natural-étnico), não a província romana (sentido administrativo), bem mais ampla. BROWN, R. E., Introdução ao Novo Testamento, p. 631-632; FERREIRA, J., Gálatas, p. 17-18.

${ }^{5}$ GONZAGA, W., Os conflitos na Igreja primitiva entre judeus e gentios a partir das cartas de Paulo aos Gálatas e Romanos, p. 108-219; SILVANO, Z. A., Carta aos Gálatas, p. 448-450; SILVANO, Z. A., Gálatas.

${ }^{6}$ Esta cronologia tradicional é suficiente para as questões tratadas neste artigo. BROWN, R. E., Introdução ao Novo Testamento, p. 573 (onde também a cronologia revisionista).
} 
- Entre 53 e 58 d.C.: depois de passar por Cesareia (e Jerusalém? At 18,22-23), Paulo inicia, a partir de Antioquia, a $3^{a}$ viagem de missão (At 18,23-21,17), no fim da qual ele se encontra com Tiago $(21,18)$.

A situação que deu origem à Carta aos Gálatas pode ser situada na segunda ou no início da terceira missão de Paulo. Paulo menciona na carta também um conflito ocorrido quando ele estava em Antioquia da Síria: os "judaizantes" influenciaram Pedro e Barnabé a ponto de se retiraram da comunhão de mesa com os gentio-cristãos (Gl 2,11-14). Esse conflito revela um problema permanente que pesava sobre a missão de Paulo junto aos gálatas (e junto aos gentios em geral): os judaizantes opõem "um outro evangelho" àquele que Paulo anuncia (Gl 1,6.7). Esses "judaizantes" praticavam um tipo de proselitismo judeu-cristão, propagando sob o nome de Jesus Cristo o judaísmo observante. ${ }^{7}$ Como se explica que os gálatas, depois de terem acolhido Paulo tão bem (Gl 4,14), se voltaram para o "outro evangelho", o da circuncisão? Talvez não tivessem percebido a ruptura de Paulo e, conversos zelosos, quisessem com a pregação do Cristo também o judaísmo completo, apregoado pelos judaizantes. É possível que desejassem integrar uma religio licita, como o judaísmo, enquanto o cristianismo dos gentios passava por "ateu", visto que os gentio-cristãos não eram judeus e não praticavam os cultos reconhecidos pelo Império. ${ }^{8}$ Os gálatas podem ter achado que a circuncisão lhes daria uma identidade religiosa reconhecida.

Qual era a posição teológico-pastoral de Paulo? Segundo a opinião geral dos judeus (e dos cristãos "judaizantes"), a condição para ser considerado justo diante de Deus era a circuncisão e a pertença ao povo eleito. ${ }^{9}$ Paulo, porém, julga que, no caso de gentios que acolhessem o evangelho de Cristo, a observância da Lei mosaica não deveria constituir uma condição para serem considerados justos diante de Deus, que está acima dos "méritos" humanos. Aliás, segundo Lucas, o "Concílio de Jerusalém" tinha corroborado a posição de Paulo, ao citar o testemunho de Simão Pedro (At 15,7-11.14) e a autoridade de Tiago de Jerusalém, "irmão do Senhor" (15,14-19).

\footnotetext{
${ }^{7}$ Que R. Brown caracteriza como "full observance" (BROWN, R.; MEIER, J. P., Antioch and Rome, p. 2).

${ }^{8}$ OEPKE, A., Der Brief des Paulus an die Galater. p. 201 (mencionado em DUNN, J. D. G., Epistle to the Galatians, p. 336); BARCLAY, J. M. G., Obeying the Truth, p. 58-60; WILLIAMS, S. K., Galatians, p. 27.

${ }^{9}$ Geralmente o AT deixa em aberto a situação dos gentios na salvação. Focaliza Israel, que tinha a Aliança, as promessas e o dever de corresponder a isso para ser justo.
} 
Paulo enfoca, em Gálatas e Romanos, a situação análoga da circuncisão, no caso do judeu, e da não circuncisão, no caso do gentio. Nenhuma das duas situações garante a salvação. Nem o gentio no paganismo, nem o judeu na circuncisão podem se considerar justos sem a graça de Deus, que se revela em Cristo e se recebe na fé $(\mathrm{Rm} 3,30){ }^{10}$

Para mostrar que é possível ser considerado justo por Deus sem a Lei, Paulo recorre ao caso exemplar de Abraão (Gl 3,6; Rm 4,3). Antes da eleição de Israel, Abraão agradou a Deus porque creu na promessa (incrível) de posteridade e terra. De modo semelhante, os gentios agradam a Deus quando creem em Jesus Cristo, sem a Lei de Moisés e sem exigência prévia de obra alguma, como fica claro em Rm 9,9-13. As eleições de Deus não dependem de uma obra humana e nem da observância material da Lei de Moisés. Abraão foi justo para Deus sem a Lei. Se para Israel a eleição se configura em torno da Aliança do Sinai e da Lei de Moisés, os gentios, assim como Abraão, são chamados sem a Lei. Não podemos condicionar a graça de Deus à obra humana, nem nos (van)gloriar diante de Deus de nossas obras humanas, que também são um dom de Deus (Ef 2,10).

Paulo faz então questão de mostrar que a Lei, como instituição de Israel, não é necessária. Recorrendo a um paradoxo retórico, descreve Jesus como um condenado da Lei, o que significa o fim da Lei como condição para a justificação por Deus e para o dom do Espírito (G1 3,11-14).

Porém, "noblesse oblige": uma vez contado como agradável a Deus, o agraciado tem que se realizar nessa nova condição e mostrar a "verdade prática" da "justiça" que lhe foi "imputada" de graça. Também para Paulo, a sola fides ${ }^{11}$ não basta para cumprir a vocação cristã, mas sim, a fé com o fruto que ela produz, ${ }^{12}$ o fruto do Espírito, que consiste em atitudes práticas (Gl 5,22), que Tiago chama de obras.

\footnotetext{
${ }^{10}$ Isso se refere aparentemente à vida como justo, não ao Juízo.

11 A "sola fides" não é uma fórmula de Paulo, mas de Lutero (BROWN, R. E., Introdução ao Novo Testamento, p. 954, nota 22). Mais tarde o protestantismo desenvolveu a catequese dos "cinco solas". Ver também WILLIANS, R., Justificação, p. 974.

${ }^{12}$ A metáfora do frutificar é frequente nas palavras de Jesus nos evangelhos (Mc 4,20 e par.; Mt 7,16-20 e par. etc.)
} 


\subsection{A salvação universal em Gálatas e Romanos}

A mensagem expressa pela Carta aos Gálatas - o "evangelho de Paulo" (G1 1,11) - anuncia, por um lado, a salvação universal pela adesão a Cristo e, por outro lado, o caráter gratuito dessa graça, acima de toda kauchēsis ou autoglorificação da "carne", isto é, da pessoa humana em base de seus critérios humanos. "Carne" é, por exemplo, a autossuficiente observância das "obras (= prescrições) da Lei". O alvo das críticas de Paulo não é a Lei, mas o fato de transformá-la em título de glória da "carne", kauchēsis. ${ }^{13}$ Paulo não escreve para abolir a Lei de Moisés, mas para mostrar que a salvação em Cristo é acessível a quem não está (e não precisa estar) no regime dessa Lei. A liberdade cristã, na Carta aos Gálatas, não é, em última instância, a libertação da Lei judaica, mas a liberdade para servir, desimpedidamente, aos irmãos e irmãs, tornando-se escravo deles pelo amor (Gl 5,1.13) e produzindo os frutos do Espírito. Paulo não admite que uma lei que se mostrou incapaz de salvar, e até se tornou cúmplice da maldição que atingiu o Crucificado (Gl 3,13), impeça a participação no mistério da graça e da gratidão no amor, para o qual ele mesmo tinha sido "alcançado" (Fl 3,12), apesar de seu serviço fanático e autorreferencial (kauchēsis) à Lei.

Quanto à Carta aos Romanos, não se sabe exatamente o que levou Paulo a explicitar essa intuição num texto dirigido a uma comunidade que sequer conhecia de perto. Intenção evangelizadora, visando tanto à multidão de judeus na capital do Império quanto à população gentia ali presente? Ou harmonizar a comunidade judeu-cristã com o crescente grupo de gentio-cristãos, depois da crise da expulsão dos judeus sob o imperador Cláudio? ${ }^{14}$ Pouco importa, Romanos nos ajuda a compreender melhor a visão apaixonada que Paulo expressa em Gl 3,19-20: "De fato, eu morri para a Lei para que eu viva para Deus. Estou crucificado com Cristo. Vivo, mas não eu; é Cristo que vive em mim. O que agora vivo na carne, eu o vivo pela fé do Filho de Deus que me amou e se entregou por mim". Se Cristo se entregou por Paulo, seu perseguidor (G1 2,20), ele se entregou por todos, sem exceção.

Romanos 1-5 expõe de modo racional e, sobretudo, retórico a presença do pecado e a necessidade de salvação, tanto para os gentios quanto para os

\footnotetext{
${ }^{13}$ Por exemplo, a circuncisão, Gl 6,12-13.

${ }^{14}$ LOURENÇO, R. J., Carta de Paulo aos Romanos, p. 14; JEWETT, R., Romans, p. 59; BARBAGLIO, G., As cartas de Paulo II, p. 118.
} 
hebreus, e isso nos ajuda a perceber melhor o intuito da Carta aos Gálatas. Enquanto Gálatas reage a uma circunstância temporária, Romanos é uma exposição da doutrina da salvação universal. Recorre inicialmente (nos capítulos 1-5) à metáfora da justificação por parte de Deus, mas depois usa uma linguagem mais geral. Por isso é bom perceber que a metáfora da justificação, ou imputação de justiça, é uma especificação de um tema mais amplo.

O tema do homem justo é onipresente na literatura sapiencial, a começar pelos Salmos (S1 1). O justo é a pessoa da qual Deus se agrada, não por algum agrado superficial - uma oferta sacrifical ou algo assim ${ }^{15}$, mas por causa do "caminho" ou conduta geral da pessoa. É o "homem bom", a "mulher virtuosa", pessoas de bem, como nós dizemos. Não são necessariamente impecáveis, pois até o justo peca sete vezes ao dia $(\operatorname{Pr} 24,16)$. Evidentemente, como a Torá é a referência "comportamental" por excelência, essa justiça se mede pela conformidade à Lei (S1 119!), ainda que desde tempos antigos se saiba que as prescrições da Lei precisam da sabedoria para ser interpretadas segundo as circunstâncias da vida. Se se perguntar a um judeu tradicional quem seria um bom exemplo de pessoa justa, ele responderá quase espontaneamente: nosso pai Abraão. E quando se pergunta por quê, ele dirá: porque creu em Adonai quando lhe prometeu terra e descendência e porque, a partir daí, viveu

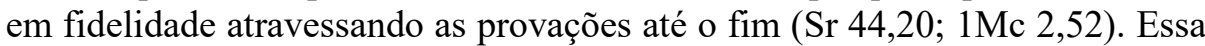
"fé fiel" é a fé de Abraão segundo Tiago (Tg 2,18-24), que acrescenta o exemplo da cananeia Raab $(2,25)$, porque também ela creu no Deus-que-é-Um" (cf. Js 2,11) e agiu em conformidade com o que acreditava. Por outro lado, também os demônios creem no "Deus-Um" e até estremecem (Tg 2,19), sinal de que simplesmente crer não basta!

Já o tema da justificação corresponde a uma abordagem mais específica: a declaração ou imputação de justiça. Em Gl 3,1-6, a menção à "justificação" (de Abraão) se segue ao tema da efusão do Espírito acontecida entre os gálatas independentemente da Lei de Moisés (G1 3,2). Essa efusão foi em virtude da "escuta da mensagem da fé " (akoe pisteōs), e a "escuta", na tradição do Shemá, inclui a prática daquilo que é ensinado. Gl 3,6 cita Gn 15,6, usando em relação à justificação de Abraão o termo logizesthai, que podemos traduzir como ser creditado ou imputado; a elaboração deste tema será feita em Romanos 4. Ora, uma vez que recorre à metáfora da justificação no sentido forense, Paulo entra

${ }^{15} \mathrm{O}$ sacrifício só agrada a Deus se oferecido a partir de um comportamento justo ( $\mathrm{Sr}$ 35,18-19 LXX etc.), ou com a condição de que reine a hesed (Os 6,6). 
no campo jurídico, que tem a ver com satisfação de culpa e pagamento de dívida. ${ }^{16}$ Avançando além da comum compreensão "comportamental" de "justo", é como se Paulo perguntasse: "Quem pagou para que essa pessoa seja justa, isenta de divida? Quem pagou, para que Deus me conceda, de graça, a sua graça?" A resposta é: Jesus Cristo. Diversas metáforas e tipologias servem para explicitar essa resposta: o sacrifício de expiação pelo sangue ( $\operatorname{Rm} 3,25$; Rm 5,9), o Servo Padecente que pagou por nossos pecados ( $\mathrm{Rm} 4,25)$, o cordeiro pascal (1Cor 5,7), e até metáforas jurídico-comerciais, por exemplo, o documento da dívida cravado na cruz $(\mathrm{Cl} 2,14)$.

\section{Tiago}

\subsection{O autor em seu contexto}

Embora nem sempre seja necessário identificar o autor real de um texto para compreender o processo comunicativo, a tentativa de situá-lo histórica e culturalmente pode fornecer alguns indícios facilitando a compreensão interna do texto.

O Novo Testamento menciona cinco Tiagos:

(1) Tiago Maior, apóstolo, filho de Zebedeu e irmão de João (Mc 1,19), mencionado 16 vezes, martirizado pouco tempo depois de Jesus, em 44 d.C. (At 12,2);

(2) Tiago filho de Alfeu, apóstolo (Mc 3,17 e par.);

(3) Tiago, irmão de Jesus e de José, Simão e Judas (Mc 6,3 e par.; Jd 1), mencionado como chefe da comunidade de Jerusalém em At 12,17; 15,13 e 21,18; Gl 1,19; 2,9.12; e como beneficiário de uma aparição, em 1Cor 15,17. Implicitamente, está entre os "irmãos" de Jesus mencionados em At 1,$14 ;{ }^{17}$

\footnotetext{
${ }^{16}$ Aprofundamentos em: BROWN, C. et al., Justiça, p. 1117-1140; KOCH, K., șdq, p. 639-668; SCHNEIDER, G., dikaios, p. 981-984; KERTELGE, K., diakosynē, p. 985-1000; KERTELGE, K., dikaioō, p. 1000-1013.

${ }^{17}$ Em Mc 6,3, Jesus é chamado "o carpinteiro, o filho de Maria, irmão de Tiago, de José, de Judas e de Simão". Não é preciso, para nossa exposição, dirimir se os irmãos de Jesus são filhos de Maria, esposa de José, ou não. De toda maneira, a tradição patrística responde que não, e um indício nessa linha é que, em Mc 15,40.47; 16,1, a Maria que acompanha Maria Madalena na hora da cruz, da sepultura do sepulcro vazio (a "outra Maria" em Mt 27,61) é identificada como mãe de Tiago Menor e José, mas não como mãe de Jesus. Se a Maria de Mc 15,40.47; 16,1 fosse
} 
(4) Tiago Menor, filho da Maria, mãe de Tiago e de Simão, que foi testemunha da cruz e do sepulcro (Mc 15,40.47; 16,1 e par.);

(5) Tiago, pai do apóstolo Judas (Tadeu?) (At 13,1).

É altamente provável que Tiago Menor, irmão de José (Mc 15,40.47; 16,1) (item 4), é o Tiago que, juntamente com José, Simão e Judas, é contado entre os irmãos de Jesus em Mc 6,3 (item 3) e mencionado em Jd 1. Ora, Tiago Menor não está na lista dos doze apóstolos - o que teria dado mais peso à sua carta. A tradição posterior resolveu isso identificando-o com o apóstolo Tiago, filho de Alfeu. ${ }^{18}$ Mas, mesmo sem essa identificação, e mesmo se a carta for um pseudoepígrafo, ${ }^{19}$ Tiago Menor, irmão do Senhor, tem um belo currículo para ser chefe da Igreja de Jerusalém e apadrinhar a carta: (a) fazia parte da "família extensa" de Jesus, o clã de Nazaré, ainda reticente em relação à pregação de Jesus (Mc 6,3 e par.; 3,21.31-35); (b) sua mãe testemunhou a crucificação e o sepulcro vazio (Mc 15,40.47; 16,1) e, conforme Mt 28,9, encontrou o Ressuscitado; (c) ele estava com os irmãos de Jesus na primeira comunidade de Jerusalém (At 1,14); (d) ele teve uma aparição do Ressuscitado (1Cor 15,7). Como primeiro chefe da igreja-mãe de Jerusalém, ele bem pode ter sido aquele que deixou suas exortações como legado depois de sua morte, ocorrida em 62 d.C. ${ }^{20}$ Segundo Eusébio de Cesareia, seu sucessor foi Sim(e)ão, filho de Cléofas - também "irmão do Senhor". ${ }^{21}$ Havia um laço forte entre Jerusalém e os judeu-cristãos ${ }^{22}$ de Antioquia, segunda ou terceira cidade do

a mãe de Jesus, por que Marcos não a chamou assim nessa cena tão emocionante? Só Jo 19,2527 introduziu a mãe de Jesus perto da cruz ao lado das outras mulheres. - O termo "irmão" frequentemente indica parentes em geral ou membros do clã, tanto na Bíblia hebraica como na LXX (que só duas vezes especifica que alguém é "'primo", anepsiós, e isso, em contexto matrimonial).

${ }^{18}$ Assim Jerônimo, entre outros. Contra essa identificação: BROWN, R., Introdução ao Novo Testamento, p. 945-946, notas 1 e 2.

${ }^{19}$ Naquele tempo a pseudo-epigrafia era praxe: o nome de autoria prestigiava um personagem meritório e também o próprio texto. A epígrafe da Carta de Judas (Jd 1) sugere um arranjo nesse sentido.

${ }^{20}$ Segundo Flávio Josefo, Antiquitates Iudaicae, 20.9.1, apud BROWN, R., Introdução ao Novo Testamento, p. 946.

${ }^{21}$ OBERLINER, L., Brüder u. Schwestern Jesu, p. 713-714.

${ }^{22}$ Apesar de certas críticas a esta terminologia, utilizamos os termos "judeu-cristão" e "gentiocristão" segundo a aceitação costumeira de cristãos das primeiras gerações, provindos, respectivamente, da religião judaica ou da gentilidade. 
Império e capital da província siro-fenícia, que incluía a Palestina. ${ }^{23}$ At 11,19 30 atesta a chegada de judeu-cristãos em Antioquia a partir de Jerusalém (o profeta Ágabo, At 9,28!) e menciona Barnabé e Saulo levando a Jerusalém a ajuda dos cristãos antioquenos. As dificuldades surgidas em Antioquia foram apresentadas ao "Concílio de Jerusalém" (At 15,1-2). Por causa de sua importância administrativa e situação geográfica (porto), Antioquia logo se tornou um centro de expansão missionária (At 13,1-3 etc.).

\subsection{A "religião pura e sem mancha"}

A Carta de Tiago não contém a abordagem tipicamente cristosoteriológica de Paulo, como observou Lutero, ${ }^{24}$ mas ela apresenta inegavelmente a mensagem cristã da universalidade da salvação, articulada não em torno de categorias étnicas (judeus e gentios), mas éticas e sociais (ricos e pobres). A salvação não é o apanágio dos ricos, considerados como beneficiados por Deus, enquanto na realidade, muitas vezes, cometem injustiça. A salvação é para os humilhados e os pobres, cujo grito atravessa as nuvens, como ensina a sabedoria (Sr 35,18 LXX). E o rico deve se gloriar quando é humilhado, pois é então que Deus age para elevá-lo (Tg 1,9-10; 4,6; $1 \mathrm{Sm} 2,8$; S1 113,7-8).

Concentremos agora nossa atenção sobre o capítulo 2 da Carta de Tiago. A carta menciona a "justificação" somente em Tg 2,21-26, como corolário da fé que se manifesta nas ações. Chegou-se a considerar esta passagem como corpo estranho ou interpolação, ${ }^{25}$ mas essa opinião hoje é abandonada.

Situando o tema no contexto maior, podemos considerar 1,2-18 uma espécie de introdução, e 1,19-27 como chave para os temas específicos desenvolvidos em $2,1-5,6 .^{26}$

Constata-se uma conexão temática entre 1,19-27 e 2,1-26. ${ }^{27}$ Em 1,19-27, Tiago aponta sinteticamente a atitude prática a ser adotada por seus

\footnotetext{
${ }^{23} \mathrm{~A}$ esta cidade estão ligados os conflitos com os judaizantes mencionados em At 15,1-5 e em Gl 2,11-14. A distinguir de Antioquia da Pisídia.

${ }^{24}$ LUTHER, M., Vorrede zum Neuen Testament, datada de 1545.

${ }^{25}$ Assim: BOUWMAN, G., Tiago (Epístola), p. 1507-1508.

${ }^{26}$ FRANKEMÖLLE, H., Der Brief des Jakobus, p. 135-138, trata 1,2-18 como prólogo. A unidade 1,19-27 é o primeiro (e emblemático) desenvolvimento da temática geral evocada em 1,2-18: a perseverança na busca da perfeição praticando o que é justo diante de Deus.

${ }^{27}$ MOO, D. J., Tiago, p. 77.
} 
destinatários. Com ecos da literatura exodal, lembra os princípios: pronto para escutar, lento para a ira (Ex 34,6; Dt 4,31). A ira não opera a dikaiosynē tou theou $(1,29)$. Essas observações preparam o leitor para uma instrução sobre a dikaiosyne, a justiça "ao modo de Deus" (não a justificação forense), que o ser humano é chamada a operar diante de Deus em nome de sua vocação criacional (Gn 1,26-27). ${ }^{28}$ Evidentemente, essa impostação de Tiago não exclui, mas antes supõe que a justiça é dom inicial de Deus, como Paulo explica em Gálatas e Romanos. ${ }^{29}$ Deus dá ao ser humano a justiça como um dom para que ele a possa traduzir/realizar praticando boas obras (como expõe Ef 2,8-10).

Deus implantou nos fiéis a Palavra que é capaz de salvar $(1,21)$. Essa Palavra deve ser praticada, para não acontecer como acontece à pessoa superficial, que olha seu rosto no espelho e logo depois esquece como era $(1,22-$ 24). O que nos dá identidade é a prática dessa "palavra implantada", e essa prática pode se basear na "lei perfeita, a da liberdade", a ser praticada com coerência e integridade. ${ }^{30}$ Visto que a Lei é a grande dádiva de Deus, lei régia (Tg 2,8), quem se considera religioso não pode excluir uma parte da lei, por exemplo, o controle da língua (Tg 1,26; Ex 20,16; Dt 5,20 etc.), ${ }^{31}$ pois, senão, sua prática religiosa (thrēskeia) é vã ilusão (mátaios, Tg 1,26). Em linguagem popular nossa: o cumprimento da lei não pode ter furos, deve ser à prova de água. Como conclusão, Tiago formula uma frase sintética, metonímica, ${ }^{32}$ paradigmática e clara: "A religião pura e sem mancha diante do Deus e Pai é esta: assistir órfãos e viúvas em suas dificuldades e guardar-se da contaminação do mundo" $(1,27)$.

O termo que geralmente é traduzido como "religião", em grego soa thrēskeia e significa, exatamente, o cumprimento das obrigações religiosas. Para um judeu piedoso (como o autor e os leitores implícitos da carta), esse termo evoca o cumprimento adequado da tōrah, como sugere também Tg 1,26. Tiago se aproxima aqui das fórmulas que se encontram nos evangelhos e em Paulo, enunciando o primeiro, supremo ou até tudo-abrangente mandamento do

${ }^{28}$ Outra interpretação: a ira não é a justiça de Deus porque Deus é lento para a ira ( $\mathrm{Nm} \mathrm{14,18;} \mathrm{Ne}$ 9,17; Sl 86,15; 103,8; 145,8), como deve ser também o fiel segundo Tg 1,19.

${ }^{29}$ Dom inicial, não garantia final, mas "dom e tarefa".

${ }^{30}$ TAMEZ, E., Santiago, p. 76-89.

${ }^{31}$ Tema retomado no cap. 3 .

$32 \mathrm{O}$ mandamento citado representa, metonimicamente (pars pro toto), toda a lei referente ao amor ao próximo e as demais leis "sociais", expressas sobretudo no coração da "Lei da Santidade" (Lv 17-26), a saber, em Lv 19,9-18. 
amor ao próximo (Mc 12,28 e par.; Gl 5,14; Rm 13,8-10; Jo 13,34-35; 1Jo $4,11)$. Não se trata do cumprimento ritual da Lei (Tiago nunca fala disso), mas da ética. ${ }^{33}$

A partir dessa chave $(\operatorname{Tg} 1,27)$ podemos interpretar as advertências e exortações que se seguem no corpo da carta (Tg 2,1-5,6). A frase de 1,27 é programática. A "prática religiosa (thrēskeia) pura e sem mancha" terminologia que evoca a Lei da Santidade de Lv $19^{34}$ - corresponde mais ou menos ao que nós chamamos de "prática religiosa", e essa é, em primeiro lugar, ética. Isso se baseia na antropologia teológica de Tiago: ${ }^{35}$ se o ser humano é criado à imagem e semelhança de Deus (Gn 1,26-28), a verdadeira veneração de Deus consiste em levar essa imagem à perfeição, como ensina a parte introdutória Tg 1,2-12. É neste quadro que se deve entender a "lei perfeita" de que fala $\mathrm{Tg} 1,25$.

Tiago não sente nenhum problema em elogiar a Lei. Sente-se bem à vontade com ela. Sua experiência não é a de Paulo, e sim a de um judeu imbuído da tradição sapiencial. Seu amor pela Lei não é obsessivo, mas generoso. Embora sua comunidade provavelmente se constitua de cristãos "da circuncisão", não mostra nenhum interesse em leis rituais. Considera a Lei como orientação global da vida (em hebraico: tōrah). Por isso, ela deve ser observada integralmente, mas de maneira interpretada. Atitude semelhante encontramos em seu quase contemporâneo Filão de Alexandria, que faz também uma hermenêutica geral da tōrah, inclusive das leis rituais, explicandoas como alegorias da vida. ${ }^{36}$ Já em Tiago, a hermenêutica é ética.

\footnotetext{
33 Também Os 6,6; Sr 35,1-5 etc.

${ }^{34}$ Tiago se interessa especialmente nos mandamentos éticos de Lv 19,9-18. O tema da perfeição lembra a alusão a Lv 19,1 nas Bem-Aventuranças Mt 5,48; Lc 6,36. Esse tema da "perfeição" não deve ser entendido num sentido ascético-voluntarista, mas no sentido da teologia antropológico-criacional da teologia sacerdotal em Gn 1,26-28, a vocação à semelhança com Deus. (Apesar de sua insistente referência ao Templo como ponto de referência para o Israel pósexílico, a teologia dos círculos sacerdotais não é necessariamente ritualista, mas, muitas vezes, bem humanista e sapiencial).

${ }^{35}$ FRANKEMÖLLE, H., Der Brief des Jákobus, p. 305-320.

${ }^{36}$ Fílon de Alexandria, Legum Allegoriae, recorre à interpretação alegórica das leis, pois para interpretá-las "literalisticamente" não havia mais jeito em seu ambiente.
} 


\subsection{A fé eficaz, critério da práxis cristã}

O cap. 2 de Tiago critica, à luz da chave de 1,27, as atitudes vigentes nas comunidades dos destinatários. Fazendo a leitura do texto como está, na sua sincronia, vemos em 2,1 o "referencial cristão" da exortação que se segue. ${ }^{37} \mathrm{O}$ fato de o resto do capítulo ser sabedoria judaica não o impede de ser cristão, sobretudo porque essa sabedoria não fica reservada aos sábios e entendidos, mas é disponibilizada aos pequenos, como proclama o rabi Jesus de Nazaré (Mt 11,25-27 e par.).

Tg 2,1 pergunta se o comportamento descrito a seguir corresponde a um critério coadunável com "a fé de Nosso Senhor Jesus Cristo da glória". Traduzimos esta expressão de modo literal, inclusive a preposição de, para deixar clara que Tiago não pensa na fé do enunciado confessional tendo Cristo por objeto, mas no pacto de adesão e fidelidade ligada a Jesus, portador do título que é a denominação grega de YHWH, reforçado com o adjunto "da glória", que exprime sua proximidade de Deus! ${ }^{38}$ Tg 2,1 adverte que não pode ser (man)tida juntamente com a fé do "Senhor Jesus" a "acepção (preferência) de pessoa" (prosōpolēmpsia), proibida por duas passagens importantes da tôrah, Dt 1,17 e Lv 19,15: o juiz não deve julgar pela aparência (prosōpon), nem a favor do pobre, abrindo a porta à demagogia e o clientelismo, nem do rico, favorecendo o suborno.

Tendo descrito, ironicamente, em 2,2-3, a recepção diferenciada de pobres e ricos na sinagoga, Tiago pergunta se seus destinatários não julgam com critérios perversos (v.4). E lembra que Deus escolheu os pobres como sendo ricos no contexto da fé e herdeiros do Reino (pois pertencem à comunidade eleita), enquanto os leitores (típica classe média?) desprezam os pobres (v.6a) e por sua vez são perseguidos pelos ricos (v.6b-7). Propõe então o critério que se encontra no centro da "Lei da Santidade" (Lv 17-26), logo

\footnotetext{
${ }^{37}$ Advertidos pela crítica literária, devemos levar em conta a possibilidade de o versículo 2,1 ter sido introduzido (pelo autor ou por um glosador) para dar um teor mais cristão ao capítulo ou à carta toda, que, senão, poderia passar por mera sabedoria judaica. Essa prevenção, porém, não modifica a mensagem.

38 A forma pistis (tou) Iésou ocorre em Rm 3,22.26; Gl 2,16; 3.22; Tg 2,1; Ap 14,12. O significado é variável e não pode ser enquadrado na opção entre genitivo subjetivo (a fé que Jesus tem ou dá) e objetivo (a fé em Jesus). Parece antes um adjunto adverbial exprimindo lealdade, adesão e pertença, ou até práxis, como o hebraico 'emunah (Hb 11). Poder-se-ia dizer que, aqui, se trata de um genitivo de relação.
} 
depois da proibição da prosōpolēmpsia (Lv 19,15), a saber: o amor ao próximo (Lv 19,18).

Tanto no ensino judaico como na "fé de Cristo" o critério central da ética é o amor ao próximo. Julgar pela aparência é incoadunável com isso. Para lembrar a prática integral da tōrah, Tg 2,11 acrescenta outro exemplo, que faz parte do ensino tradicional do judaísmo e é usado também por Jesus, no Sermão da Montanha: não matar, não adulterar (Mt 5,21-30). A interpretação de Jesus é emblemática: supera a letra pelo espírito do respeito ao próximo. Segundo mestre de Nazaré, o espírito da tôrah não se confina numa lista de regras, mas se percebe na escuta diante da face de Deus (Dt 6,4: shema' yisrael). Essa atitude corresponde à lei régia, soberana, a lei da liberdade, que permite agir, desimpedidamente, segundo o coração que seja realmente justo (Mq 6,8). O critério que se coaduna com a "fé de Cristo" é a tôrah na sua integridade, ${ }^{39}$ como Jesus lembra antes de explicar, no Sermão da Montanha, alguns dos principais mandamentos (Mt 5,17-20).

No mesmo espírito da integridade da tōrah e da integridade diante de Deus e seu povo, nosso autor passa a ensinar a eficácia dessa lealdade cristã em relação à tradição normativa e sapiencial do judaísmo, que constitui a comum base de compreensão do autor e seus leitores (Tiago e "as doze tribos na dispersão", 1,1). O próprio Jesus conclui o sermão da Montanha (ou da Planície) com o apelo a “escutar e pôr em prática” o seu ensinamento (Mt 7,24; Lc 6,47). É sob este ângulo que Tiago questiona as atitudes vigentes entre seus destinatários (Tg 2,4). Ele exprime sua atitude crítica em duas palavras: "Que adianta?" (v.14a.16b). Reveladora é a pergunta referente a quem não tem ação eficaz: "A fé pode salválo?" (v.14b). Trata-se da fé que salva, não uma fé meramente dogmática ou confessional, mas uma fé que se comprova em ações $(1,27)$.

Para um judeu que se torna cristão, a fé não é algo intelectual, mas adesão, pertencimento, lealdade, 'emet/'emunah: no caso, fidelidade eficaz a Jesus como Senhor (2,1), orientada pelo tōrah bem entendida (2,8-9). Essa é a fé que salva.

Depois disso, recorrendo novamente, como em 2,2-3, a exemplos irônicos (no gênero da diatribe), Tiago põe em xeque a fé que não salva: a fé que não se

\footnotetext{
${ }^{39}$ Entendemos por integridade não a soma quantitativa e extensiva, mas a "indefectibilidade", a qualidade intensiva, a perfeição que realiza plenamente o intento, no sentido em que Mt 5,48 reformulando a lei da santidade Lv 19,1 - ensina a sermos perfeitos ou íntegros como o próprio Pai Celeste.
} 
comprova em ações. ${ }^{40}$ Entra em cena alguém que diz ter fé (2,14aa), mas Tiago acrescenta que ele não tem obras a apresentar $(2,14 \mathrm{ab})$; e pergunta: "Que adianta? Tal fé tem poder de salvar?" $(2,14 \mathrm{~b})$. Depois, envolve na diatribe os próprios leitores - "alguém de vós" $(2,16)$ - e mostra a ineficácia e o vazio de sentimentos piedosos que não se traduzem em ações concretas. Os exemplos lembram o sermão final de Jesus (Mt 25,31-45) e a sabedoria judaica (Pr 3,27-28; Sr 4,1-4 etc.). E conclui: a fé que não mostra frutos na prática é um cadáver $(2,17)$.

\subsection{Também os demônios creem}

É nesse contexto que surge a questão da fé por si só, "a fé somente". A fé por si só, sem ações eficazes pode salvar alguém? Contrastando alguém que se gaba de ter fé, um outro interlocutor (que parece identificar-se com o autor) responde que mostrará sua fé por ou a partir de $(e k)$ suas obras e ações $(2,18)$. E, de modo irreverente, o autor observa que também os demônios creem no Deus único dos judeus, e estremecem $(2,19) .{ }^{41} \mathrm{Ou}$ seja, só crer, ter temor e até tremor diante de Deus em nada contribui para a salvação. E nesta altura, Tiago insere os exemplos de Abraão $(2,23)$ e da prostituta cananeia, Raab $(2,25)$, que creram no Deus de Israel (Gn 15,6; Js 2,9-13) e confirmaram sua fé pela prática. Por isso foram considerados justos, com base dessa fidelidade na prática que cooperou com a fé (synērgei, 2,22). A conclusão é que alguém é "justificado com base naquilo que faz e não pela fé somente" $(2,24)$. A fé que salva é a fé com obras, não a fé por si só. ${ }^{42}$

\footnotetext{
${ }^{40}$ A semelhança com 1Jo 3,18 não é mera coincidência.

${ }^{41}$ Comparar com Mc 1,24 e par.

42 "Não sabemos exatamente o que Tiago entende por fé, mas ele nos esclarece [...] o que entende por obras: [...as] boas obras das quais nos falam continuamente os evangelhos em relação com os atos libertadores de Jesus e que têm a ver com ações de justiça. [...] Contrariamente, são Paulo critica as obras relacionadas com o ritual, os sacrifícios e outros tipos de oferendas e festividades. Em sua luta contra os judaizantes, Paulo cancela o pensamento tradicional da primazia desse tipo de obras, para centralizar a fé como única via de salvação. Em momento algum coloca as obras de justiça contra a justificação. Ao contrário, ele as coloca como frutos do espírito, que nascem pela fé" (TAMEZ, E., Santiago, p. 85; trad. nossa). Também FRANKEMÖLLE, H., Der Brief des Jakobus, p. 477. Observa VOUGA, F., A Carta de Tiago, p. 97: "Em Gn 22, como em Gn 15 , trata-se da fé de Abraão. Mas trata-se da fé posta à prova $(\mathrm{Gn} 22,1)$, que a obediência à palavra de Deus (Gn 22,1-2) obriga a arriscar tudo, inclusive a promessa e a esperança. Ora, é

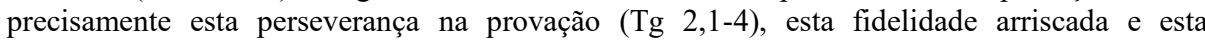


Por causa da coincidência na terminologia da justificação e na referência a Abraão (Gn 15,6), geralmente se pensa que Tiago esteja respondendo à suposta tese de Paulo da justificação "só pela fé", baseada no mesmo texto da Escritura. Para verificar essa opinião devemos examinar três pontos: a questão da sola fide, a terminologia da justificação e o uso de Gn 15,6.

a) Paulo nunca falou em sola fide; em nenhum lugar em Paulo está escrito que só a fé é que salva. ${ }^{43}$ Que a fé, entendida como fidelidade, salva é uma expressão tradicional baseada em Hab 2,3 e presente também em outros ramos da tradição, mas não se fala em "a fé somente".

b) O termo "justificação" tem, em Tg 2, outra semântica que em Gálatas e Romanos. Em Tiago, refere-se à justiça praticada diante de Deus $(\operatorname{Tg} 1,20)$ e levado até o fim (1,4, a "obra perfeita" como o ouro acrisolado), enquanto para Paulo, em Gálatas e Romanos, se trata da justiça gratuitamente outorgada por Deus para entrar na comunidade dos que estão sendo salvos - se forem fieis e produzirem frutos dignos da justiça que lhes foi imputada, como ensinam diversos textos do Novo Testamento, inclusive de Paulo.

c) $\mathrm{O}$ uso de um mesmo texto da Escritura - o exemplo de Abraão (Gn 15,6) - com uma interpretação diferente, em Paulo e Tiago, não é necessariamente fruto de confronto ou contato literário direto, visto que a interpretação adotada por Tiago já ocorre em Sr 44,19-20 (LXX) e 1Mc 2,52, escritos quase dois séculos antes. Tiago não é original aqui, ele reproduz a tradição sapiencial. Original é Paulo, ao ensinar que o acesso à salvação não supõe obras (subentendido: "da Lei"), pois Abraão foi justificado antes que a Lei com suas obras existisse. Uso diferente de argumentos escriturísticos semelhantes constata-se também quando se compara Gl 4,21-28 com Jo 8,3138 (o filho permanece na casa, o escravo não), pela simples razão de essas passagens da Escritura representarem o "material didático" usado pelos rabinos em diversas oportunidades.

Se Tiago não se opõe diretamente a Paulo, seu texto afasta, factualmente, uma atitude "quietista" que consistiria num cristianismo de braços cruzados e língua solta, censurado em 2Ts 3,10-13 como interpretação distorcida das palavras de Paulo - atitude contrária daquela dos judaizantes, mas igualmente errônea. Enquanto os judaizantes na Galácia são criticados por Paulo por não

obediência árdua que Tiago chama 'obras da fé' [...]". E observa em nota que "fé" e "obras" não designam a mesma coisa para Paulo e para Tiago.

${ }^{43}$ Ideia apresentada na nota 11. 
entenderem o "seu" evangelho da salvação universal (G1 1,7.8; At 14,27) e exigirem as "obras de Lei" (At 15,1-5), a carta de Tiago, a partir de outra problemática (a de 2Ts) vem completar, de fato, a expressão apaixonada e unilateral de Paulo. Porém, ela não foi escrita para corrigir Paulo e sim para exortar seus leitores a uma fé operante, num momento em que o amor está arrefecendo (Mt 24,12). Se ninguém tivesse levantado a ideia de um conflito entre Paulo e Tiago, leríamos Tiago sem pensar em tal conflito. Segundo a leitura interna do texto, esse conflito não está na partitura. Tiago não faz mais do que explicitar, com a ajuda da tradição sapiencial judaica, aquilo que Jesus disse no Sermão da Montanha sobre aqueles que dizem "Senhor, Senhor" e não praticam o que ele ensina (Mt 7,21.22; 25,11): a lição da árvore que se reconhece pelos frutos e a irrevogável lei da caridade fraterna. Quem não corresponde a isso, não se salva.

\section{Paulo e Tiago}

Antes de concluir a confrontação de Paulo e Tiago, lembremos os contatos diretos ou indiretos que tiveram:

- Gl 1,19 (At 9,26-30?): encontro de Paulo com Tiago em Jerusalém, no terceiro ano depois de sua conversão.

- At 11,30: Paulo, com Barnabé, entrega em Jerusalém a coleta dos antioquenos aos anciãos (entre os quais se deve supor Tiago).

- At 15,4-35: presença de Paulo e Barnabé na reunião dos apóstolos em Jerusalém, no fim da primeira viagem, em 49 d.C.; pouco depois, Paulo se separa de Barnabé por causa de Marcos (At 15,36-39).

- Gl 2,1.9: o acordo com Cefas, Tiago e João em Jerusalém, aparentemente se referindo ao mesmo encontro de At 15,3-35. ${ }^{44}$

- Gl 2,11-14: alguns "de junto de Tiago" causam problemas em Antioquia e, contrariamente ao acordo de Jerusalém, afastam Cefas e Barnabé da comensalidade com os gentios convertidos.

- At 21,18: visita de Paulo à casa de Tiago na presença dos anciãos, no fim da terceira viagem missionária.

\footnotetext{
${ }^{44}$ Segundo o cálculo tradicional, este segundo encontro com Tiago, por ocasião do "Concílio de Jerusalém" (ano 49?), seria "quatorze anos" depois do encontro de Gl 1,19 (ano 37?) ou, mais provavelmente, depois da conversão (ano 35?). O terceiro encontro, o de At 21,17, se situaria por volta de 58-60 d.C., segundo a cronologia indicada para esse artigo, como apresentado na nota 6.
} 
Podemos dar crédito, em grandes linhas, ao testemunho cumulativo de Atos e Gálatas quanto ao contato pessoal entre Paulo e Tiago, como lembrado em At 15/Gl 2. Evidentemente, Lucas, em Atos, realça o espírito fraterno do contato entre Paulo e Tiago, pois quer mostrar que a obra de Cristo e do Espírito continuou em paz e harmonia na expansão missionária impulsionada por Paulo, enquanto Tiago, irmão do Senhor, representava a comunidade-mãe de Jerusalém.

Nesse quadro podemos situar a coincidencia de certos temas que aparecem na Carta de Tiago e nos escritos paulinos, especialmente, o tema das "obras", recorrente também na literatura sapiencial e encontrado nos escritos de Qumran. ${ }^{45}$

\begin{tabular}{|l|l|}
\hline \multicolumn{1}{|c|}{ Paulo } & \multicolumn{1}{|c|}{ Tiago } \\
\hline $\begin{array}{l}\text { Fala da fé no sentido de confiança em } \\
\text { Deus e da "fé de Cristo" proclamada } \\
\text { como evangelho (Gl 3,22) e base da } \\
\text { justificação (Gl 2,16). }\end{array}$ & $\begin{array}{l}\text { Fala da "fé de Cristo" como critério } \\
\text { de atitudes e práticas }(2,1) .\end{array}$ \\
\hline $\begin{array}{l}\text { Justificação gratuita pela fé (Gl 3,1- } \\
\text { 5; Rm 1-5). }\end{array}$ & $\begin{array}{l}\text { Justificação completada pelas obras } \\
\text { que põem em prática e confirmam a } \\
\text { fé (2,22). }\end{array}$ \\
\hline $\begin{array}{l}\text { Exemplo de Abraão que creu na } \\
\text { promessa (Rm 4,3 etc.; Gl 3,6). }\end{array}$ & $\begin{array}{l}\text { Exemplo de Abraão e de Raab, que } \\
\text { creram e agiram de acordo com a sua } \\
\text { fé (2,21-25). }\end{array}$ \\
\hline $\begin{array}{l}\text { O cumprimento da Lei na caridade } \\
\text { (Gl 5,12; Rm 10,13); a fé como } \\
\text { acesso à boas obras destinadas aos } \\
\text { fiéis (Ef 2,4). }\end{array}$ & $\begin{array}{l}\text { A Lei "régia" (o amor ao próximo) } \\
\text { como prática religiosa (thrēskeia) } \\
\text { pura e sem mancha (1,25.27; 2,8). }\end{array}$ \\
\hline $\begin{array}{l}\text { O fruto do Espírito na práxis crista } \\
\text { (Gl 5,22). }\end{array}$ & A paz fruto da justiça (3,18). \\
\hline
\end{tabular}

\section{Conclusão}

Voltemos à pergunta inicial: qual é a fé (cristã) que salva? Respondemos: tanto a fé que, à maneira de Abraão, recebe de graça e não por mérito próprio a

${ }^{45}$ GARCÍA MARTÍNEZ, F., Textos de Qumran, p. 127-128: fragmento 4Q398 2 ii 2-8. 
amizade de Deus como dom e tarefa (Gálatas), quanto a fé fiel na provação, levando suas obras a termo - igualmente à maneira de Abraão (Tiago). Mas não é sempre essa fé que se exibe em nossa sociedade.

A exibição do rótulo cristão em nossa sociedade atual aponta para uma hipertrofia do "religioso" (especialmente se for lucrativo) e um sumiço do ético. Será que se pode substituir o empenho ético por uma religiosidade empolada e um moralismo hipócrita, usados até como moeda política?

Tiago respeita a tōrah, a instrução que, desde Moisés, Israel aprendeu a "escutar" (o Shemá) e procura, nisso, o critério que é coadunável com aquilo que os fiéis aprendem de Jesus Cristo, "a fé de Nosso Senhor Jesus Cristo da glória" $(2,1)$. Esse critério não é o temor de Deus, que também os demônios têm (inclusive, até estremecerem), mas amar o próximo como a si mesmo, como ensina a velha "Lei da santidade" do Levítico. Essa é a observância religiosa pura e sem mancha (Tg 1,27).

Paulo responde a uma problemática diferente, sugerida por sua missão junto aos gentios: é necessário o regime da Lei mosaica para ser aceito (justificado) por Deus e entrar na comunidade dos que são salvos? A resposta é: "não", pois a graça de Deus é de graça e a Lei de Moisés, de alcance restrito e superada em Cristo.

Por outro lado, a comparação entre a maneira como Paulo e Tiago, cada um a partir de sua experiência e situação, elaboraram o tema da fé como escuta e dos frutos/obras que daí defluem, mostra mais convergência que diferença. Os fiéis são convidados a confirmarem, pelos frutos que produzem, a fé que receberam, em tudo isso animados pelo mesmo Espírito de Jesus Cristo. Não faz sentido brandir a bandeira de uma fé meramente nominal que fica cega diante da injustiça conjuntural e estrutural que exige inclusive ação transformadora. As obras comprovam e encarnam a fé, que não pode consistir em meras fórmulas confessionais, ritos ou práticas piedosas. $\mathrm{O}$ cumprimento "puro e sem mancha" do compromisso com Deus, consiste naquilo que Tiago chamou, emblematicamente: "visitar (= assistir) órfãos e viúvas em suas dificuldades e guardar-se da contaminação do mundo" (Tg 1,27). Ou, como pediu a Paulo: que "não nos esqueçamos dos pobres" (Gl 2,10). 


\section{Referências bibliográficas}

BARBAGLIO, G. As cartas de Paulo II. São Paulo: Loyola, 1991.

BARCLAY, J. M. G. Obeying the Truth: Paul's Ethics in Galatians. Edinburgh: Clark, repr. 1991.

BOUWMAN, G. Tiago (Epístola). In: BORN, A. van den (Org.). Dicionário enciclopédico da Bíblia. Petrópolis: Vozes, 1971. p. 1507-1508.

BROWN, C. et al. Justiça. In: COENEN, L; BROWN, C. (Orgs.) Dicionário Internacional de Teologia do Novo Testamento. São Paulo: Vida Nova, 2000. p. 1117-1140.

BROWN, R.; MEIER, J. P. Antioch and Rome: New Testament cradles of Catholic Christianity. New York: Paulist Press, 1983.

BROWN, R. E. Introdução ao Novo Testamento. São Paulo: Paulinas, 2012.

DENZINGER, H. Compêndio dos símbolos, definições e declarações de fé e moral. Traduzido com base na $43^{\mathrm{a}}$ edição alemã (2010), aos cuidados de Peter Hünermann. $3^{\text {a }}$ ed. rev. e ampliada. São Paulo: Paulinas / Loyola, 2013.

DUNN, J. D. G. Epistle to the Galatians. London: Black, 1993.

FERREIRA, J. Gálatas: a epístola da abertura de fronteira. São Paulo: Loyola, 2005. FRANKEMÖLLE, H. Der Brief des Jakobus I-II. Gütersloh: Gütersloher Verlag, 1994.

GARCÍA MARTÍNEZ, F. Textos de Qumran: edição fiel e completa dos documentos do Mar Morto. Petrópolis: Vozes, 1995.

GONZAGA, W. Os conflitos na Igreja primitiva entre judaizantes e gentios a partir das Cartas de Paulo aos Gálatas e Romanos. Santo André: Academia Cristã, 2015.

JEWETT, R. Romans: a commentary. Minneapolis: Fortress, 2007.

KERTELGE, K. diakosynē. In: BALZ, H.; SCHNEIDER, G. (Orgs.). Diccionario Exegético del Nuevo Testamento. Salamanca: Sigueme, 1996. p. 985-1000. t. 1. 
KERTELGE, K. dikaioō. In: BALZ, H.; SCHNEIDER, G. (Orgs.). Diccionario Exegético del Nuevo Testamento. Salamanca: Sigueme, 1996. p. 1000-1013. t. 1. KOCH, K. s $d q$, ser fiel en la comunidad. In: JENNI, E; WESTERMANN, K. (Orgs.). Diccionario Teológico Manual del Antiguo Testamento. Madrid: Cristiandad, 1985. p. 639-668. t. II.

LOURENÇO, R. J. Carta de Paulo aos Romanos. In: LOURENÇO, R. J.; SILVANO, Z. A. As Cartas de Paulo aos Romanos e aos Gálatas: salvos pela graça, fecundos pelo Espírito. São Paulo: Loyola, 2020. p. 13-76.

LUTHER, M. Vorrede zum Neuen Testament. Disponível em: $<$ https://www.luther2017.de/martin-luther/texte-quellen/vorrede-zum-neuentestament/index.html>. Acesso em: 03 mar. 2021.

MOO, D. J. Tiago: introdução e comentário. São Paulo: Vida Nova, 1990.

OBERLINER, L. Brüder u. Schwestern Jesu. In: BAUMGARTNER, K. et al. (Eds.). Lexikon für Theologie und Kirche. Freiburg: Herder, 1994. p. 713 714. t. II.

OEPKE, A. Der Brief des Paulus an die Galater. Berlin: Rohde, 1973.

PENNA, R. Salvação - Teologia Bíblica. In: LACOSTE, J.-Y. (Org.). Dicionário crítico de Teologia. São Paulo: Loyola / Paulinas, 2004. p. 15911596.

SCHNEIDER, G. dikaios. In: BALZ, H.; SCHNEIDER, G. (Orgs.). Diccionario Exegético del Nuevo Testamento. Salamanca: Sigueme, 1996. p. 981-984. t. 1 .

SILVANO, Z. A. Carta aos Gálatas: tradução, introdução e comentários. In: $A$ BÍBLIA: Novo Testamento. São Paulo: Paulinas, 2015. p. 448-450.

SILVANO, Z. A. Gálatas. Disponível em: $<$ http://teologicalatinoamericana.com/?p=1990>. Acesso em: 01 mar. 2021.

TAMEZ, E. Santiago: lectura latinoamericana de la epístola. San José: DEI, 1985. VOUGA, F. A Carta de Tiago. São Paulo: Loyola, 1996.

WILLIAMS, S. K. Galatians. Nashville: Abingdon Press, 1997. 
WILLIANS, R. Justificação. In: LACOSTE, J.-Y. (Org.). Dicionário crítico de Teologia. São Paulo: Loyola / Paulinas, 2004. p. 974-980.

Johan Konings

Doutor em Teologia pela Katholieke Universiteit Leuven Docente de Exegese Bíblica (Novo Testamento) na Faculdade Jesuíta de Filosofia e Teologia Belo Horizonte / MG - Brasil E-mail: konings@faculdadejesuita.edu.br

Recebido em: 05/03/21 Aprovado em: 28/05/21 